\section{ВЕЩЕСТВЕННОСТЬ ИСТОРИИ: ВАЛЬТЕР БЕНЬЯМИН СРЕДИ КАРТОННЫХ КОРОЛЕЙ, СТАРЫХ КНИГ И МЕТАЛЛИЧЕСКИХ КОНСТРУКЦИЙ}

НИКИТА ЗАГВОЗДКИН

Магистрант философии, Университет Вупперталя.

Aдpec: Gaußstraße 20, 42119, Wuppertal, Germany.

E-mail:zagvnd@gmail.com

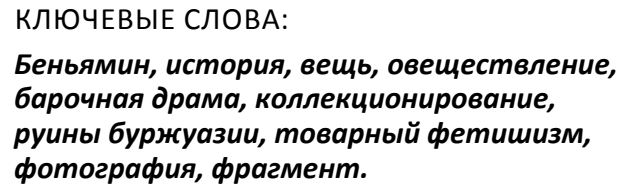

В статье исследуется ряд образов и одновременно фигур мысли, при помощи которых Вальтер Беньямин на протяжении разных периодов своего творчества представлял и осмыслял связь между вешами и историей. Для этого во множестве прозрений, догадок и перекличек, составляющих поле билософии Беньямина, выделяются основные точки притяжения его мышления и воображения: реквизит барочного театра, коллекиии старых книг и металлические конструкиии, образующие ландшабт ранней капиталистической индустрии. Каждая из этих групп предметов интерпретируется как выражение определенного способа овеществления истории, который вводит ее в пространство практики и тем самым дает человеку обешание спасения в проблематичной ситуации его времени.

Аллегорическое застывание эпохи в театральном реквизите позволяет упорядочить ее на сиене, заключение прочлого в вещзах непроизвольной памяти дает человеку шанс возвратить свою жизнь в осмысленной иелостности впечатления, а устаревшие символь классового господства буржуазии пробуждают революиионного субъекта от идеологического сна и складываются в образ утопии. Во всех трех случаях действительность превращения истории в объект и мессианский смьсл этой трансбормации фиксируются как основные черты образа мысли Беньямина. Вместе с тем каждый из синтезов времени и вещественности задает особенную плоскость для своего рассмотрения: драматически-эстетическую, трансиендентально-мнемоническую или социально-политическую. Соответственно варьируется тематика рассматриваемьх текстов, методологические предпосылки их организации и упоминаемые в них персоналии. В конце статьи совокупность этих различий возводится к языку письма Беньямина, который одновременно разделяет элементы своей мысли и сочленяет их как фрагменты расколотого иелого, интеллектуальной мозаики. Тем самым избранные форма и композиция статьи получают свое методологическое основание в рассматриваемом предмете. 
«Чтобы мир воцарился на земле, не следует уничтожать всякую вещь и потом начинать все заново; нет, нужно лишь немного подвинуть эту чашку, или вон тот куст, или камень, и так всякую вещь. Но оттого что это немногое столь трудно сделать, а меру его - столь трудно отыскать, люди осуществить такое в целом мире не способны, и к ним для этого придет мессия» ${ }^{1}$.

Эти слова принадлежат мудрому раввину из рассказа Эрнста Блоха «Die Glückliche Hand» («Счастливая рука», сборник «Следы», 1930). Но это изречение может стать введением и к текстам другого немецкого писателя и философа, Вальтера Беньямина (1892-1940). Многие его работы, написанные в разные годы и, казалось бы, не пересекающиеся тематически, посвящены той скрытой связи, которая существует между вещами, спасением и историей. Пожалуй, единственное, в чем философ не согласился бы с героем Блоха, это то, что человеку остается ждать «мессию», того, кто рассудит людей и расставит вещи по своим местам. В интеллектуальной биографии Беньямина важнейшее место занимают активные поиски упомянутой блоховским раввином «меры» и решительные попытки так или иначе «подвинуть» окружающие нас вещи, чтобы спасти заключенную в них эпоху. История этих поисков и прозрений составит предмет нашей статьи.

Конкретнее, в этой работе мы ставим цель проанализировать те вещественные образы, которые у Беньямина принимает история, равно как и связанные с ними формы мессианской практики. Такое исследование подразумевает три стадии, обозначенные в названии при помощи указания на три группы предметов, которые в своих сочинениях рассматривает Беньямин это «картонные короли», «старые книги» и «металлические конструкции». За каждой из этих фигур скрывается особое отношение между вещами и историей, которое мы разберем в каждом случае на основе интерпретации отдельного круга источников в соответствующей части статьи. По мере того как мы будем продвигаться вперед, между различными планами мысли Беньямина начнут обнаруживаться общие черты. Выделение этих повторяющихся мотивов позволит нам обосновать правомерность как поставленной задачи, позволившей объединить столь разные тексты, так и той формы, в которой мы беремся ее разрешить.

Уже в «Происхождении немецкой барочной драмы» (1925), одной из своих первых крупных работ, Беньямин сближает полюса исторического и вещественного. Контекстом их соотнесения выступает особая духовная ситуация эпохи барокко, времени мощнейшего религиозного чувства, «новой мирской воли» (Беньямин 2002, 67), которая, однако, не могла найти ни упокоения, ни даже выражения в устоявшихся формах христианской культуры. Контрреформация, нацеленная на сохранение «нерушимого господства христианства», блокировала для всякого устремления к трансцендентности возможность «религиозного

1 Цит. по книге: Болдырев 2012, 241. 
решения», «чтобы потребовать вместо него решение светское - или даже навязать его» (ibid., 67). Будучи замкнутым в имманентности мира, каждое религиозное стремление превращалось в апорию: как возможно в посюстороннем мире реконструировать опыт потустороннего, разрешить порыв к божественному без отсылки к потустороннему Богу? Именно в этих противоречиях, определяющих историческое бытие человека барокко, Беньямин видит основу, «набросок» тех произведений искусства, которые оставила нам эта эпоха (ibid., 97).

Характеризуя исторические условия возникновение немецкой драмы XVII в., Беньямин пишет: «Барочной эсхатологии не существует; и именно отсюда механизм, который собирает и экзальтирует все земное, прежде чем его настигнет конец» (ibid., 52). Отсутствие доступа к потустороннему измерению оборачивается необходимостью акцентировать земной мир. Такая установка не исчерпывается пышностью декораций и изысканностью языка, а затрагивает саму «идею», сущность барочной драматургии. Не имея возможности непосредственно обратиться к своей подлинной проблематике, эпоха выражает ее аллегорически, посредством череды фигуральных замещений: трансцендентного - имманентным, человеческого - предметным, исторического природным. Лишь эти преломления позволяют ввести морально-религиозные мотивы в сферу языка и искусства. Двойственность такого иносказания - представлять и одновременно скрывать свой предмет - Беньямин передает метафорой зеркала: «Тварный мир являет собой зеркало, в раме которого только и мог предстать перед взором барокко моральный мир. При этом неизбежны были искажения, так как зеркало было кривое» (ibid., 82).

Отчетливее всего такой характер барочной драмы может быть выражен при помощи расширенного понятие реквизита. Задействованные на сцене предметы, структура пьесы, ее сюжет и фабула, наконец, поступки и мотивы персонажей - все это является в некотором смысле реквизитом, вещью, при помощи которой эпоха ловит отражения теологической истины: бренности жизни и возможности спасти ее в этом качестве. Театральный реквизит оказывается той формой, в которую вливаются силы и свойства исторической жизни. Она застывает в кинжале, письме, короне и прочих атрибутах власти, чтобы обрести выразительный сценический образ. История замещается природой, широкая временная перспектива сокращается до декораций монаршего двора. В одном движении морально-религиозный мир раскладывается на элементы, представляющие целое в качестве осколков, а время полностью «затягивается» материальной природой. Здесь дает о себе знать та же метафизическая тенденция, что и в точных науках XVII в., стремившихся представить всякий процесс как череду статичных состояний. В этом смысле барочный реквизит подобен бесконечно малым величинам математики: и в том, и в другом случае «процесс движения во времени замыкается в пространственном отображении» и подвергается аналитическому разложению на элементы (ibid., 84).

И персонажи, и вещи выводятся барочными драматургами на сцену, чтобы служить аллегорией исходного, неизрекаемого и вместе с тем подвергшегося 
профанации теологического опыта. Беньямин пишет: «...немецкая барочная драма полностью погружается в безутешность земного мироустройства. Если ей и ведомо избавление, то оно заключено скорее в глубине роковых предначертаний, чем в осуществлении спасительного божественного умысла» (ibid., 69). Одним из языков, на которых выводятся эти предначертания, является вещественность. Герои барочной драмы по преимуществу слабы духом и бессильны перед хаотичным и бессмысленным миром, но лишь реконструкция идеи бренности на языке предметов позволяет довести «тварный характер» человека до предельной степени выражения (Ромашко 2002, 278-279). Неумолимый рок неустанно движет героя к кровавому финалу, сочленяя «порыв тварной жизни в человеке» с вещами: по словам Беньямина, «в драме рока природа человека выражается в слепой страсти так же, как природа вещей в слепой случайности, и все это по общему закону судьбы» (Беньямин 2002, 132). В результате «сами страсти принимают природу реквизита», вспышка ревности остра как кинжал не в силу метафорического переноса, а из-за аллегорического тождества: на сцене ревность и есть кинжал (ibid., 133). Только в предмете аффект обретает решающую власть над персонажами драмы рока, становясь заставшим выражением их немощности. В результате метафизическая вина человека и ограниченность его удела как бы лишаются внутреннего измерения и оседают в реквизите, а опустошенному герою остается роль игрушки в руках слепой природы.

В совершенно особом смысле аллегория господствует над монархом истинным героем барочной драмы. Как бы ни было велико его значение для политического сознания XVII в., в театре суверен - один из персонажей, и для него, как и для всех прочих героев, сцена является непреодолимой границей всех действий и мыслей. Поэтому правителю, не способному оказаться по ту сторону аллегории, остается лишь занять место в ее центре, который совпадает с центром монаршего двора. В итоге в театральном изображении суверена аллегорическое овеществление достигает своей высшей точки. Не только его тело принимает на себя могущество и власть, но его корона и одежды поглощают и замещают собой тело. В конечном итоге фигура монарха растворяется в реквизите, живое тело раскладывается на неживые предметы - детали гардероба и прочую бутафорию. Так суверенный властитель, единственный политический субъект абсолютистского государства XVII в., становится похож на куклу, картонного короля (ibid., 122-123). В некоторых сценах это проявляется в буквальной замене государя предметом реквизита, в других же - в нарочито пышных нарядах, сковывающих актера на троне.

Рисуя портрет барочного монарха, Беньямин вступает в заочную полемику с Карлом Шмиттом (1888-1985), сразу в нескольких отношениях переворачивая теорию суверенитета последнегоㄹ․ Согласно Беньямину, функция властителя состоит не в том, чтобы в критический для государства момент

2 Подробнее об этом см.: Чубаров 2012. 
воспользоваться своим правом и ввести чрезвычайное положение, а в умении его предотвращать, ведь сам status quo тварного мира катастрофичен, так что чрезвычайное положение является для него правилом, а не исключением ${ }^{3}$. Такая политическая инверсия отсылает к метафизической: если для Шмитта суверен скорее трансцендентен миру, то Беньямин в своем толковании барокко подчеркивает имманентность монарха театральному действию. Правитель находится не над сценой, а в ее глубине, как точка, в которой аллегорически фокусируются надежды и чаяния эпохи. Благодаря этим двум перестановкам Беньямин может сформулировать то принципиальное противоречие, вокруг которого из предметов реквизита складывается фигура барочного монарха.

С одной стороны, господство аллегорического виденья в барочной драме позволяет людям, обыкновенно зависящим от условий своего существования, получить над ними власть. Будучи овеществленной, история подчиняется логике своей драматической формы и становится соразмерной силам и способностям человека: с персонажами можно говорить или спорить, вещи можно передвигать и изменять, и каждое такое действие эхом раздается в истории, ведь сцена есть не что иное, как свернутое историческое время. Барочная драма вторит стремлениям своего времени, представляя сценическую задачу примирить по ходу действия персонажей и правильно расставить вещи до финала - в качестве аллегории задачи исторической (Чубаров 2012, 53, 56-57). Беньямин в этой связи пишет о «реставрационной философии истории» (Беньямин 2002, 68).

Этой реставрации барочная драма требует от монарха (ibid.). Если история аллегорически тождественна скипетру, то в руках его сжимает именно суверен. Наказывая интригана, спасая невиновных и освобождая вещи от власти судьбы, правитель действует как великий защитник общественного порядка (ibid., 50-51). Заключенные в вещах морально-религиозные противоречия человеческого бытия поддаются разрешению через перестановку предметов, осуществляемую властителем. Полное исполнение реставрационной миссии монарха принадлежит уже теологической плоскости: в конечном счете суверен должен пересоздать мир, включив эпоху в новую надисторическую целостность, «заменить непостоянство исторических событий неколебимой конституцией законов природы» (ibid., 61) и возвратить человечество к «райскому вневременному состоянию» (ibid., 83). Именно это, по мнению Беньямина, удается испанской драме в ее лучших образцах. Так, в пьесах Кальдерона (1600-1681) «состояние творения все еще дает отблеск солнца милости», а «судьба развертывается как стихийный дух истории, и представляется вполне логичным, что никто кроме короля, великого реставратора нарушенного порядка творения, не в состоянии уладить дело» (ibid., 130).

3 Эту мысль Беньямин повторит в тезисе VIII работы «О понятии истории» (1940). См.: Беньямин 20123, 241-242. 
С другой стороны, Беньямин констатирует, что в немецкой барочной драме эта задача не была решена. В кривом зеркале аллегории у немецких драматургов грозный суверен неизменно предстает немощным болванчиком, вполне соразмерным правителям многочисленных германских княжеств времен Тридцатилетней войны. Немецкой драме так и не удалось справиться с кукольной зажатостью государя и преодолеть зазор между его задачами и возможностями. В итоге Шмиттовской доктрине деционизма Беньямин противопоставляет тезис о неспособности правителя принимать решения: в чрезвычайных обстоятельствах, требующих его вмешательства, монарх не может распорядиться своей абсолютной властью и потому как в действии, так и в бездействии остается пленником своих страстей и регалий (ibid., 57-58). Суверен не способен противостоять мрачному ходу вещей, ведущему монарший двор к кровавому финалу, и такая развязка является ничем иным, как аллегорией всемирной катастрофы, на которую обречена природа, лишенная малейшего проблеска трансцендентной благодати.

Барочная теория суверенитета, как ее формулирует Беньямин, сталкивается с апорией: в чистой имманентности не только предмет, но и субъект практики редуцирован. Разлагая моральный мир на элементы и выражая его в вещах, аллегория обещает спасение через упорядочивание предметов - однако это движение одновременно уничтожает ту силу, которая могла бы воссоздать мир в новой блаженной целостности. Поэтому немецкая барочная драма неспособна самостоятельно дать образец разрешения духовных устремлений своей эпохи. Однако в этом поражении Беньямин видит указание на следующий шаг, который необходимо совершить: от искусства к его критике. С самого начала барочная драма предполагала читателя как точку возможного выхода из круга сковывающих ее противоречий. Необходимость занять к искусству дистанцию предопределяет возникновение философской критики, которая, рассматривая эстетический предмет из новой исторической перспективы, в будущем примет на себя задачу его реконструкции, продолжения и завершения. Барочный читатель рассматривал произведение искусства с дистанции того знания, которое оно должно было репрезентировать, и в этой позиции уже был заключен зародыш последующей критики ${ }^{4}$.

Эта несамодостаточность произведения искусства означает, что оно с самого начала творится в ожидании последующего прочтения, цель которого не

4 Ср. Беньямин, 2002, 189-190: «Дело в том, что взгляд, которому было бы довольно созерцания самой вещи, был в то время редкостью. Читатель был настроен усваивать произведения в самом широком круге их связей, и в гораздо меньшей степени занятие ими было, как в более позднее время, частным делом, никому не подотчетным. Чтение было обязательным и наставляющим. В качестве соответствия подобному настроению публики понятной оказывается массовость, лишенность тайны и широта произведений. Они ощущают свое предназначение не столько в том, чтобы распространяться во времени, сколько в том, чтобы заполнять место в земном, современном мире. В определенном смысле они утратили свою ценность. Однако именно поэтому в их дальнейшем существовании содержится развернутая критика». 
может ограничиваться эстетической идентификацией с героем пьесы, герменевтическим прояснением авторской мысли, заключенной в первоисточнике, или символическим изображением идеального образца. Беньямин пишет: «дело исторической критики обнаружить, что функция художественной формы как раз в этом и состоит: превращать исторические элементы содержания, лежащие в основе всякого значимого произведения, в содержательные элементы философской истины» (ibid., 190-191). Отталкиваясь от исторических условий XVII в., барочная драма желает ответить на вопросы о тварной природе человека и возможности его спасения. Однако аллегория, наглядно репрезентирующая это, в сущности, философское стремление, одновременно замыкает его в себе, скрывает от современников его подлинный «исток» (Ursprung) и потому предопределяет его неудачу. Только критика как саморефлексия искусства может выйти из этого порочного круга. Она занимает к предмету познавательную, языковую и историческую дистанцию, чтобы впервые представить внутреннюю истину произведения и тем самым стать его исполнением, «новым рождением, в котором эфемерная красота полностью исчезает, а произведение утверждается как руина» (ibid., 191). «В аллегорическом строении барочной драмы, - добавляет Беньямин, - подобные руинные формы спасенного произведения искусства (trümmerhafte Formen des geretteten Kunstwerks) явно проступают с самого начала» (ibid.; Benjamin 1991a, 358).

Лишь в критическом истолковании судьба картонного короля приобретает свое подлинное значение, выраженное в понятиях суверенитета и имманентности. Строго говоря, исследователь немецкой барочной драмы не восстанавливает теологический контекст аллегории, а впервые создает его, собирая фрагменты творений барочной драматургии в целостность философского трактата. Однако в этот самый момент противоречия оказываются словно бы взятыми в скобки. В философском прочтении суверен уже находится в некотором, хотя бы отрицательном, отношении к трансценденции, тяжесть вещей на сцене уравновешивается легкостью, которую они приобретают в языке критика, разрушительное воздействие реквизита не достигает субъекта-зрителя и нейтрализуется, а предметы раскрываются как аллегории исторического бытия человека благодаря комплексному осмыслению эпохи барокко. В этом смысле можно сказать, что «атеологическая теология» и «трансценденция в имманентности» являются проектами, реализуемыми только задним числом, как фигуры речи, описывающие исходное событие неудачи овеществления истины, чтобы преодолеть его в языке. Таким образом, при всей проблематичности целей барочной драмы, и, в частности, аллегорического синтеза вещественности и истории, Беньямин тем не менее питает надежду на исполнение устремлений барокко, однако связывает ее уже с иными формами, немыслимыми без определенной дистанции от первоисточника.

«Происхождение немецкой барочной драмы» позволяет выделить общие принципы, которыми Беньямин руководствуется при соотнесении вещей и истории. Отношение этих двух полюсов мыслится при помощи аллегорического 
тождества, в рамках которого вещи не указывают на свое историческое время, а выступают способом его бытия в художественной реальности барочной пьесы. Такая трансформация является предпосылкой спасительной практики упорядочивания, в которой субъект, барочный монарх, создает новую религиозную целостность, расставляя предметы на сцене. Однако этот мессианский потенциал может быть реализован лишь постфактум, не картонным королем, пойманным в апории суверенитета, а философским критиком, который созерцает руины барочного искусства и дает им в толковании новую жизнь.

В общем виде подобная установка сохранится и в более поздних работах Беньямина. Философ будет мыслить соединение мира вещей и истории как действительный синтез, несущий в себе скрытые мессианские возможности. Изменится, однако, конкретная постановка вопроса. На место театрального реквизита как формы аллегорической репрезентации действительности в эпоху барокко придут другие системы вещей, по-новому вбирающие в себя широкую временную перспективу. В свою очередь, тот факт, что спасение (Erlösung) может быть лишь отложенным, приведет мыслителя к проблеме памяти, понятой в качестве пространства встречи с прошлым, места особого отношения с ним. Эта тема, намеченная в книге о немецком барокко (ibid., 16-17), сыграет значительную роль в последующих попытках философа придать истории вещественный контур. Так, связь предметов, прошлого и памяти окажется в центре работы Беньямина «О некоторых мотивах у Бодлера» $(1939)^{5}$.

Ясно, что память при этом трактуется значительно шире, чем одна из психологических способностей человека наряду с остальными. Когда Беньямин в начале своих рассуждений со ссылкой на Бергсона (1859-1941) называет память «решающим моментом в философском анализе опыта» (Беньямин $20156,118)$, то он выводит исследование на трансцендентальный уровень. Вопрос о формах доступа к прожитой жизни переосмысляется как вопрос об условиях возможности опыта как такового. Для Беньямина трансформация процессов артикуляции воспоминания в XX в. означает изменение способа данности мира сознанию, т. е. самого отношения человека с действительностью. В феноменах, к которым Беньямин обращается по ходу работы, можно в одинаковой степени увидеть свидетельства притупления памяти и упадка опыта: газета вытесняет рассказ, машинная дрессировка - ремесленный навык, опредмеченный бег механических часов - наполненное время памятного календаря. Здесь получают развитие тенденции, намеченные еще в ранней статье «О программе грядущей философии» (1917). Полемизируя в этой работе с неокантианством, Беньямин стремится внести в трансцендентализм историко-культурное измерение и расширить категорию опыта за пределы классической новоевропейской теории познания (см.: Беньямин 2012б).

5 Эта работа является одной из частей проекта незаконченной книги «Шарль Бодлер. Поэт в эпоху зрелого капитализма». См. рус. пер.: Беньямин 2015 а. 
Размышляя о механизмах, конститутивных для памяти человека индустриальной эпохи, Беньямин обращается к творчеству Пруста (1871-1922). Будучи одним из первых переводчиков «В поисках утраченного времени» на немецкий язык, философ интерпретирует это произведение как «попытку синтетического порождения в сегодняшних общественных условиях опыта» (Беньямин $20156,120)$. Эта мысль впервые была высказана Беньямином в эссе «К портрету Пруста» (1929). Романный цикл «В поисках утраченного времени» описывает не жизнь, как она прошла, и даже не жизнь, как она была пережита автором, а сам процесс припоминания, «возникновение ткани воспоминания» (Беньямин 2004a, 244). Поставив себе, казалось бы, элементарную задачу рассказать о собственном детстве, Пруст был вынужден на протяжении семи томов своеro magnum opus прослеживать работу памяти, чтобы достигнуть единственной цели - осуществить генезис опыта и вернуть себе жизнь, которую он забыл и которая оттого стала для него чуждой

Опираясь на такую интерпретацию замысла «В поисках утраченного времени", Беньямин констатирует, что задача вспомнить вовсе не является тривиальной, а возможности памяти в современном обществе существенно ограничены. Доступ к прошлому оказывается сложнейшей проблемой для искусства и философии. Чтобы эту проблему сформулировать и решить, Беньямин вводит важную дихотомию, которую он также заимствует из Пруста - отличие произвольной и непроизвольной памяти, mémoire volontaire et mémoire involontaire.

Произвольной называется память в обычном значении слова. В ее основе лежит решение вспомнить то, что когда-то случилось. Руководствуясь этим стремлением, сознание напрямую обращается к прошлому, чтобы вызвать его к жизни в процессе воспоминания. Однако непосредственность этого целенаправленного акта оборачивается его деструктивным характером. Чтобы описать произвольную память с этой стороны, Беньямин использует язык психоанализа и привлекает работы Теодора Рейка (1888-1969), ученика Фрейда. Сознание, выступая как защитный механизм психики, рассеивает внешние

6 Мысль о невообразимой сложности самого простого рефреном повторяется в разных работах Беньямина, посвященных его любимым авторам: от трудности назвать адрес своего дома у Пруста (Беньямин 2004а, 252) до необходимости преодолеть вечность, чтобы побелить угол комнаты у Кафки (Беньямин 2013, 9). Эти замечания говорят чрезвычайно много о взглядах философа. Беньямину поразительным кажется обычное и повседневное, так что модус его философского удивления можно было бы пояснить словами дедушки из рассказа Кафки «Соседняя деревня» (1920): как мы можем решиться поехать верхом в близлежащее поселение, не боясь, что на это уйдет вся наша жизнь? Восхождению из опыта к его началам следует предпочесть тогда другую метафору - погружения в опыт, к тем тяжестям, ограничениям и противоречиям, которые заключены в самых простых его элементах, будь то память или окружающие нас вещи. Для Беньямина, этот отсвет ничто, затрагивающий нашу повседневность, должен стать одной из главных тем самокритики разума, которую философия осуществляет после трансцендентального поворота Канта. Потому мыслитель и заключает: истинное познание тождественно “оправданию» (Беньямин 20126, 31), т. е. обоснованию своего предмета с точки зрения его внутренних невозможностей. 
и внутренние процессы возбуждения. Аналогичным образом оно действует и по отношению к их следам, совокупность которых и образует человеческую память. Следовательно, подобная форма воспоминания не столько сохраняет пережитое, сколько защищает от него как от некоего шока. Поэтому события, возвращаемые произвольной памятью, лишены своей наглядности и выразительности. Приобретя пространственно-временные координаты, они замыкаются в себе и потому выпадают из неделимого потока нашей жизни. Так опыт нейтрализуется и низводится до пассивной материи, находящейся в распоряжении активного сознания (Steiner 2004, 173).

Напротив, в непроизвольной памяти прошлое не пересекает деструктивный порог осознания. Беньямин пишет: «частью mémoire involontaire может стать только то, что не было “пережито" явно и сознательно, с чем субъект не знаком как с “переживанием"» (Беньямин 20156, 124). Обыгрывая этот контраст, философ даже сближает непроизвольную память с забытьем. Если Пенелопа ночью распускала то, что соткала днем, то Пруст пишет полотно своей жизни ночью, как величественный ковер забвения, который порвался бы от дневного света допытывающегося сознания (Беньямин 2004а, 244-245). Другой образ мы находим в заметке «Раскапывать и вспоминать» («Ausgraben und Erinnern», 1932): подобная память является не инструментом для исследования случившегося, а медиумом, средой, которая хранит прошлое так же, как земля хранит древние города - скрывая и одновременно сохраняя их (Benjamin 1991e) $)^{7}$.

На возможность такого отношения с прошлым Беньямин указывает цитатой из Фрейда: поскольку "“осознание и сохранение следа памяти несовместимы в рамках одной системы", <...> накопление "длительных следов как основы памяти" о процессах возбуждения - дело “других систем", которые не следует смешивать с сознанием» (Беньямин 20156, 123-124). Иными словами, чтобы расширить пространство воспоминания необходимо не просто ограничить сознание, а передать его функцию иным элементам памяти. Именно они должны обеспечить представление минувшего. Если в произвольной памяти процесс конституирования воспоминания проходит непосредственно, то в непроизвольной в него включаются определенные медиумы (Травников 2015, 32-33).

Одним из таких медиумов для Беньямина выступают вещи окружающего мира. Когда человеку в том или ином предмете являются «соответствия» (или, как Беньямин пишет в другом месте, «подобия»), то эта вещь перестает выражать лишь саму себя и выходит за собственные границы ${ }^{8}$. Она становится точкой, из которой начинают разворачиваться воспоминания. Так окружающие нас предметы могут участвовать в работе непроизвольной памяти, причем

7 Об археологической метафоре памяти у Беньямина см.: Emden 2003, 217-220.

8 О «подобиях» (Ähnlichkeit) у Беньямина см.: Беньямин 2012е; о «соответствиях» (correspondances): Беньямин 20156, 154-162. 
в качестве ее действительных компонентов, а не простых психологических стимулов или ассоциаций, как это происходит в мнемонической технике дворца памяти. Опыт прожитой жизни действительно заключен в предмете и потому может быть через него актуализирован, возвращен вспоминающему человеку. Воскрешаемые образы черпают силу и яркость в конкретности физических вещей, и потому не случайно в теории памяти Беньямина особую роль играет самое насыщенное и материальное из чувств - обоняние 9 .

Разумеется, хрестоматийным примером здесь является эпизод с печеньем мадлен в романе Пруста «По направлению к Свану» (1913), первой книге из цикла «В поисках утраченного времени» (Беньямин 20156, 120). На протяжении многих лет воспоминания автора о городе Комбре, где он провел часть своего детства, были блеклыми и бедными, пока однажды вкус мадленок не перенес его на сотни страниц в прежние времена. Ограниченность сознания преодолевается благодаря вещи, вокруг которой располагаются слои непроизвольной памяти. Одно вызывает другое в этой ткани человеческой жизни, о плотности и неделимости которой красноречиво свидетельствует тот факт, что Пруст при подготовке книг к публикации не исправлял выявленные корректорами ошибки, а переписывал страницы целиком (Беньямин 2004а, 245).

Обобщая свои наблюдения, Беньямин рассуждает о тайной связи между окружающими нас вещами и прошлым. Сущность этого родства приоткрывает поэзия. Если красота, как пишет философ, действительно несет в себе встречу с давно ушедшим, то первые сонеты бодлеровского сборника «Цветы зла» (1857) повествуют о безвозвратно утерянном (Беньямин 20156, 154-158). Путь к нему ведет поэта через мир вещей, каждая из которых может стать ключом к предыдущей жизни. Беньямин в этой связи пересказывает наблюдение Пруста из его последнего романа «Обретенное время» (1927): Бодлер «мог искать, например, в запахе женщины, в аромате ее волос или груди, значимые соответствия (die beziehungsvollen Korrespondenzen), которые даровали ему в результате “лазурь огромного свода небес" или “гавань, полную огней и мачт" »

9 Ср.: «Никто из тех, кому знакомо то особенное упорство, с которым воспоминания сохраняются в запахах (но ни в коем случае не запахи в воспоминаниях!), не сможет объяснить случайностью особую чувствительность Пруста к запахам... Запах - вот определяющий смысл для того, кто забрасывает свои сети в море temps perdu» («К портрету Пруста») (Беньямин 2004a, 261). Ср. также фрагмент из «О некоторых мотивах у Бодлера», где философ пишет о подавлении сознания времени в обонянии (Беньямин 20156, 158-159). Интересно, что во второй главе “Диалектики просвещения» (1944) Адорно и Хоркхаймер связывают воспоминание о древнем счастье как раз с ароматом лотоса, поедателей которого, так называемых лотофагов, встречает Одиссей (Адорно, Хоркхаймер 1997, 84-85). Можно предположить, что расширение понятия материи, в том числе в философии марксизма, подразумевает сегодня актуализацию ее чувственных элементов и возвращение субъекта, переживающего их в опыте. Не последняя роль отводилась бы при этом запахам и обонянию, открывающим доступ к определенному уровню трансцендентальной предметности. Ориентиром здесь могло бы быть проницательное замечание Адорно о том, что материализм является способом «иннервации» метафизики, - наделения нервными клетками и придания ей чувствительности (Адорно 2003, 325). 
(ibid., 158; Benjamin 1991b, 641) ${ }^{10}$. Память и творчество сближаются, а вещь служит началом не только воспоминания, но и поэзии ${ }^{11}$.

Эссе Беньямина «Я распаковываю свою библиотеку» (1931), посвященное истолкованию фигуры коллекционера, воспроизводит то же движение памяти среди и посредством вещей. Множеством перекличек связан этот текст с романами Пруста, в особенности с «Обретенным временем» (Таганов 2015). Лирический герой эссе, под маской которого скрывается сам автор, разбирает ящики с книгами и вспоминает различные истории из своей жизни. «Легенды Танаквилы» Бахофена и «Шагреневая кожа» Бальзака пробуждают воспоминания о Швейцарии, где мыслитель учился во время Первой мировой войны, «Фрагменты из наследия молодого физика» Риттера возвращают на прошлогодний берлинский аукцион, а два альбома с облатками, доставшиеся от матери, напоминают о детстве. Эти образы - не частные отступления от основной темы эссе. Раскрывая смысл охватывающего коллекционера влечения, они показывают, как человек получает возможность запечатлеть, вспомнить и рассказать свою личную историю при помощи собранных предметов. Раскладывая старые книги, Беньямин воссоздает полотно своей собственной жизни, от городов, где он приобретал находки для коллекции, до тех комнат, в которых эти фолианты и альбомы хранились (Беньямин 2004д, 444).

С точки зрения логики образа, старые книги из эссе Беньямина обнаруживают сходство с картонными королями барочных драматургов, а в работах «О некоторых мотивах у Бодлера», «К портрету Пруста» и «Я распаковываю свою библиотеку» в общем виде повторяется схема, знакомая нам по «Происхождению немецкой барочной драмы». История, индивидуальное и коллективное прошлое, принимает форму вещей, чтобы предстать перед человеком. Тем самым между принципиально разными уровнями бытия совершаются диалектические скачки: жизнь сворачивается до события, а событие - до

10 Прилагательное «beziehungsvoll» дословно значит «отсылающий», «несущий в себе связку», «намекающий». В таком случае под «die beziehungsvollen Korrespondenzen» следует понимать такие соответствия, которыми поэт размыкает для себя новое поле поэтических смыслов.

11 Это философ уяснил себе еще с малых лет. В книге воспоминаний «Берлинское детство на рубеже веков» (1934) Беньямин описывает забаву из своих детских лет, в которой свернутый «особым образом, как это было принято в старину» детский чулок одновременно играл роль и мешка, и его содержимого (Беньямин 2012а, 71). Запустив в такой кулек руку и захватив его воображаемую начинку, нужно было, медленно разворачивая чулок, ее вынуть. Мгновение, когда чулок полностью выворачивался наружу, маленькому Беньмину казалось "ошеломляющим событием»: «"начинка" - вот она, передо мной, а кошелька, в котором она находилась, нет!» (ibid.). Также и в поэзии форма и содержание, внешняя и внутренняя стороны, в конечном счете, совпадают. Беньямин вспоминает: «Сколько раз ни повторял я этот опыт, все было мало. Он показывал мне, что форма и содержание, покров и сокрытое суть едины. Он учил меня извлекать правду из поэзии...» (ibid.). Эту же историю Беньямин рассказывает, когда пишет о структуре мира снов и тоске Пруста по минувшему («К портрету Пруста») (Беньямин 2004а, 248). 
единичной вещи (Беньямин 20123, 248). Однако эта трансформация перспективы оборачивается для человека спасительной возможностью. Стремясь вспомнить случившееся, он обращается к непроизвольной памяти, заключенной в предметах, и проходит этот путь в обратном направлении. В конечном итоге он обретает не знание, а себя самого. Лишь в момент воспоминания человек впервые и по-настоящему проживает свою жизнь. Словно подводя итог как прошлым, так и будущим своим рассуждениям, Беньямин пишет, что Пруст, написав о своем детстве, «справился с невероятным, вмиг состарив весь мир на целую человеческую жизнь. Но именно эта концентрация, внутри которой все, что обычно способно только на увядание и закат, в одно мгновенье пожирает себя, и есть то самое омоложение. "В поисках утраченного времени" это бесконечная попытка зарядить целую жизнь высшим присутствием духа» («К портрету Пруста») (Беньямин 2004а, 257).

Тем не менее эссе о коллекционировании заканчивается если не мрачно, то двусмысленно. Начав в полдень, герой добирается до последнего ящика с книгами после полуночи, когда в соответствии со знаменитым афоризмом Гегеля сова Минервы начинает свой полет. Познание, которое она несет, одновременно знаменует конец жизни осмысляемого предмета. Так и тип собирателя, обрисованный Беньямином, исчезает в современном буржуазном мире, где господствуют общественные коллекции, массовое производство и культ новизны ${ }^{12}$. Устремленное вперед человечество оставляет эту фигуру позади, в XIX в., так что Беньямин описывает коллекционера так же, как вызывают призраков. Подобно приведению, собиратель появляется из глубины прошлого, чтобы в конце эссе вновь раствориться среди старых книг. В этом заключается еще один ответ на вопрос, почему повествование заканчивается в полночь час, когда, согласно представлениям барочных авторов, на сцену выходят духи умерших (Беньямин 2002, 134-136).

Но и другое обстоятельство беспокоит Беньямина в феномене коллекционирования и, шире, в овеществленной памяти о прошедшем. Непроизвольный характер такого рода воспоминания не только защищает его от воздействия сознания, но и ставит саму возможность его осуществления в зависимость от случая. Ведь и Пруст лишь волею судеб пробует печенье мадлен, отчего он уже в первом романе своего цикла может сделать удручающий вывод: былое находится «в какой-нибудь вещи <...>, там, где мы меньше всего ожидали его обнаружить. Найдем ли мы эту вещь при жизни или так и не найдем - это чистая случайность» (Беньямин 20156, 121). Спасительный потенциал такой практики памятования ограничен ходом вещей, неподконтрольных нашей воле.

Вызвано это тем, что вспоминающий человек выступает как частное лицо, «приватье» (Steiner 2004, 104-105). Замыкаясь в себе и отказываясь от любой иной точки опоры, он оказывается непомерно слабее внешнего мира.

12 Ср. также: Беньямин 2000, 160-161. 
Раскрывая эту взаимосвязь, Беньямин пишет о «радикальном самопогружении» Пруста и, следовательно, его «отчужденности от реальной действительности», которые обусловили одновременно силу и слабость его личности. «Марсель Пруст умер от той же неопытности, которая позволила ему написать свое произведение» (Беньямин 2004а, 260), - как выразился французский журналист Жак Ривьер.

Поэтому в целом высокая оценка французского писателя не противоречит тому, что в работах Беньямина звучат и критические нотки по отношению к Прусту. Сужение поля непроизвольной памяти в современном обществе, а также ее случайный характер подталкивают философа к поиску нового способа соотнести предметы, историю и человека. Для этого Беньямин стремится диалектически осмыслить те социальные процессы, которые стирают фигуру коллекционера и старят его и без того уже старые книги. Это значило бы увидеть в проблеме предпосылки к ее преодолению, т. е. попытаться прочитать в негативных тенденциях знаки их возможного мессианского разрешения.

Так в центре внимания Беньямина оказывается процесс устаревания вещей человеческого обихода, который ускоряется по мере того, как общество все решительнее переустраивает себя, увлекаемое вперед идеями прогресса. Как представляется, Беньямину удалось открыть определенную диалектику старения, которая вновь приводит его мысль к точке пересечения сфер вещественного и исторического. По мнению философа, вещи, выпавшие из бега времени и потому ставшие старомодными, в буржуазном обществе приобретают новый всемирно-исторический смысл: они начинают исполнять революционную функцию.

В последней части работы «Париж, столица девятнадцатого столетия» (1935) Беньямин как свершившийся факт отмечает, что «развитие производительных сил превратило символы стремлений прошлого столетия в развалины прежде, чем распались представляющие их монументы... С потрясением товарного хозяйства мы начинаем понимать монументы буржуазии как руины, хотя они еще и не распались» (Беньямин 2000, 167). Предметы, бывшие век назад выражением чаяний и стремлений господствующего класса, сегодня устаревают и выбрасываются на обочину истории. Однако эти «руины» и осколки не исчезают без следа, а попадают в некую темпоральную складку. Они находятся по ту сторону нашего времени сразу в двояком отношении. Как хлам устаревшие вещи существуют позади современности - но вместе с тем как предвозвестники освобождения они принадлежат грядущему будущему и служат его проводниками. Общественное бытие отживших свой век вещей отмечено этой асинхронией исторического времени, внутри которой они заряжаются революционно-мессианским значением ${ }^{13}$. На языке «Происхождения

13 Об искривлениях времени, коридорами которых следует «мессия», философ пишет также в работе «Франц Кафка»: Беньямин 2013, 40-41. 
немецкой барочной драмы» мы могли бы сказать: символы буржуазного мира XIX в. становятся аллегориями его границ, единовременные целостности превращаются в расколотые единства, в которых слышится «бормотание прошлого» (Беньямин 20156, 157; Джеймисон 2014, 127-128).

Дело не только в том, что вещи, в прошлом сосредотачивавшие в себе коллективное воображаемое целой эпохи, ее желания и мечты, служат напоминанием обо всех тех, кто в наступившее будущее не попал и не попадет, и не только в том, что такие предметы наглядно демонстрируют историческую - и потому конечную - природу капитализма. Подобные артефакты обладают практической действенностью: они приближают социальные преобразования тем, что шокируют зрителя своим отталкивающим видом и временной инородностью. Взяв за отправную точку русский формализм (В. Шкловский, Р. Якобсон, Ю. Тынянов и др.) и вдохновленный эпическим театром Брехта (1898-1956), Беньямин разрабатывает теорию шока как одно из центральных звеньев своей философии (Иглтон 2009, 79-85).

Эти размышления затрагивают и интересующую нас область. Шоковое воздействие устаревших предметов обихода состоит в том, что они, приостанавливая автоматизм нашего восприятия, блокируют те скрытые от рефлексии идеологические механизмы, которые действуют в нашем сознании. В результате наблюдатель оказывается перед необходимостью вынести свое собственное, личное суждение о мире. Это воздействие возвращает человека к самому себе и способствует формированию субъективности, которая может в революционном акте противопоставить себя обществу и взять на себя ответственность за историческое свершение, направленное на всестороннее преобразование общественной жизни. Таким образом, обломки мечтаний предшествующих поколений разрушают тот гармоничный мир, который ныне творит воображение господствующего класса (Джеффрис 2018, 121-123).

В этой связи для Беньямина особую роль играет метафорика сна и пробуждения. Если чрезмерная рационализация и безоговорочная вера в развитие образуют сон современного общества, то опредмеченные в вещах грезы прошлого вызывают шок и тем самым помогают нам от этого состояния очнуться. Сновидения минувшей эпохи выступают сегодня как источник ясности, по поводу чего философ замечает: «использование элементов фантастических видений при пробуждении - хрестоматийный случай диалектического мышления», один из примеров хитрости мирового разума, о которой Гегель рассуждал в «Лекциях по философии истории» (Беньямин 2000, 167). В этом описании прерывания сна есть место и звуковому образному ряду. К примеру, в конце работы «Сюрреализм: последняя моментальная фотография европейской интеллигенции» (1929) Беньямин так обрисовывает коллективный портрет представителей сюрреалистического движения: «Выражение их лиц, всех до одного, смахивает на циферблат будильника, звонящего беспрерывно» (Беньямин 20046, 282). Позднее, уже со ссылкой на самих сюрреалистов, 
мыслитель опишет XIX в. как «шумы», которые врываются в коллективный сон XX в. и будят своих толкователей (Benjamin 1991f, 998) ${ }^{14}$.

Вместе с тем историческая функция предметов, выпавших из социальноисторической топики, не ограничивается их шоковым воздействием. Подобные вещи не только укрепляют сознание восстающего класса, но и позволяют увидеть картину спасенного человечества, являя собой фрагмент той утопии, которая наступит после революции. На этот аспект Беньямин намекает еще в работах о коллекционере, своеобразно обыгрывая язык марксистской политической экономии (Беньямин 2000, 161; Беньямин 2004д, 434-435). Вместо того чтобы рассматривать свою коллекцию как совокупность потребительных или меновых стоимостей, настоящий собиратель придает ей исключительно «любительскую стоимость» (Liebhaberwert). Так коллекционер освобождает предметы своего увлечения от формы полезности, исключает их из сферы рыночного обмена и позволяет им выскользнуть за пределы буржуазного мира, ведь капитализм, согласно Беньямину, накладывает свой отпечаток не только на людей, но и на вещи. В результате в круге собранных коллекционером предметов проскакивает мессианская искра - в них ему приоткрывается «более совершенный мир, в котором люди хотя так же мало наделены тем, в чем они нуждаются, как и в мире обыденном, но вещи в нем свободны от тяжкой обязанности быть полезными» (Беньямин 2000, 161) ${ }^{15}$.

Разрушая фигуру буржуа-коллекционера, общественная модернизация одновременно освобождает саму деятельность коллекционирования от привязки к сфере частной жизни и случайных артефактов. Поэтому индивидуальное отношение приватье к предметам его интереса может быть расширено до коллективного отношения субъекта к устаревшим вещам вообще. В творчестве новых миров «страсть коллекционера сродни страсти революционера» (Арендт 2003, 223), поскольку каждый из них по-своему является ребенком, омолаживающим вещи в игре. Отличие этих двух фигур в том, что обещание спасения, лишь украдкой воплощенное для героя эссе «Я распаковываю свою библиотеку» в собранных им старых книгах, приобретает в революционном хламе конкретную наглядность. Здесь контраст между тем, что господствует, и тем, что было выброшено на свалку истории, достигает своего апогея. Вещи, навсегда отринутые и потому вечно несвоевременные, теряют все

14 См. также развернутый анализ темы сна и пробуждения у Беньямина в статье С. Травникова: Травников 2015.

15 Беньямин отказывается от того, чтобы противопоставлять эксплуатацию вещей (природы) эксплуатации людей, между тем как эта оппозиция фигурировала не только у социалистов-современников типа Иосифа Дицгена (Беньямин 20123, 243-244), но и у классиков марксизма. Например, Энгельс восторгается перспективой на место «управления лицами» поставить «управление вещами» (Энгельс 1961, 224-225), с чем Беньямин едва ли согласился бы. Одним из источников вдохновения для философа была утопия Фурье (17721837), примиряющая природу и человека. Отчасти к этим мыслям Беньямина восходит и последующая критика понятия труда у представителей Франкфуртской школы. См. об этом подробнее: Джеффрис 2018, 127-130. 
определения, связывающие их с существующим миром. Они не только перестают быть товарами, носителями меновой и потребительной стоимости, но и выпадают из всех нарративов господствующего класса, из истории его побед, его культуры, его ценностей, его целей, его оправданий и т. д. Только тогда самые обычные вещи могут стать воплощение утопии, совершенного состояния социального бытия, к которому обществу еще предстоит прийти (Погребняк 2018, 62-64).

Первыми свободу обретают не люди, а вещи. Вектор развития буржуазного общества таков, что постистории раньше достигают предметы, которые самой социальной динамикой исключаются из хода времени. В судьбе человечества особую роль играет «мусор истории» (Бекмеметьев 2016). Здесь предельно заостренной формы достигает темпоральное сознание модерна, сводящее вместе мгновение и вечность (Хабермас 2003, 14-15). Для Беньямина, полнота времени, бесконечно великое, достигается лишь в точке, в бесконечно малом. В феноменологических терминах, только избегающее взгляда, абсолютно незаметное в истории может привести ее смысл к явленности. Все эти противоречия балансируют на признании одного факта: история в обычном значении слова, как направленная вперед стрела и как рассказ о победах и свершениях, есть идеологема господствующего класса ${ }^{16}$. Устаревшие, ненужные вещи совершенно чужды такому виденью, поэтому именно ими может оперировать революционная фантазия, ищущая в современности источник радикально иного.

Обрисовывая мир вещей, запечатленный в романе Андре Бретона «Надя» (1928), Беньямин пишет о «великом бессознательном», которое вдохновляет массы на революционную борьбу (Беньямин 20046, 270). Именно в этом, как и во многих других произведениях сюрреалистов, по его мнению, происходит открытие двух исторических сторон устаревших предметов: их шокового воздействия и утопического импульса. Философ пишет, что французский сюрреализм «первым обнаружил энергию революции, таящуюся в “старье”, в первых металлических конструкциях (Eisenkonstruktioinen), зданиях фабрик, самых ранних фотографиях, вымирающих предметах, кабинетных роялях, платьях, каких не носят уже пять лет, местах светских сборищ, вышедших из моды. О том, как такие вещи соотносятся с революцией, никто лучше этих авторов не знает. Как нищета, притом вовсе не только социальная и архитектурная, но и нищета интерьеров, нищета порабощенных и порабощающих вещей, превращается в революционный нигилизм, до этих ясновидцев и толкователей не понимал никто» (ibid., 268-269; Benjamin 1991d, 299).

16 Ср., например, «О понятии истории» (Беньямин 2012з), включая не вошедшую в русское издание знаменитую черновую заметку Беньямина о революции как стоп-кране в локомотиве истории (Benjamin 1991c, 1232), а также работу «Капитализм как религия» (1921) (Беньямин 2012в). Сходную мысль Беньямин высказывает, интерпретируя мотивы деятельности революционера Огюста Бланки (1805-1881): «решимость устранить существующую несправедливость» вовсе не обязательно предполагает «веру в прогресс» (Беньямин 2015в, 217). 
Судя по приведенному высказыванию, не понимал этого, по мысли Беньямина, и Маркс. Тем не менее многие его идеи были усвоены и переосмыслены Беньямином. Особое место в их ряду занимает предложенная в «Капитале» (1867) теория фетишизации - процесса, в котором отношения между людьми замещаются отношениями между предметами (Маркс 2015, 128-139). С одной стороны, Беньямин перенимает понятие товарного фетишизма и использует его критически. Присоединяясь к марксистам, философ негативно оценивает овеществление социальных связей в буржуазном обществе (Беньямин 2000, 158-160; Беньямин 2004в, 374-375; Беньямин 2012ж, 229-231 и др.). Но, с другой стороны, Беньямин резко отклоняется от этой традиции, поскольку сам буквально придает революции предметный облик. Все-таки в старых металлических конструкциях, прежде служивших бездушным символом промышленного капитализма, а теперь исполняющих мессианско-утопическую функцию, человеческая природа социального освобождения как будто бы затемняется, так что вполне закономерно возникает вопрос, не ведет ли концепция вещественности Беньямина вопреки его критике фетишизма к новому, даже более опасному роду фетишизации действительности?

Охарактеризовав в первой главе «Капитала» товарный фетишизм как «вещную видимость» (der gegenständliche Schein), Маркс оставил своим последователям широкий простор для интерпретации (Маркс 2015, 138). Так, если отождествлять вещную видимость с иллюзией сознания, то проблема устранения товарного фетишизма переносится в область субъективного, а всякое прямое или косвенное возвращение к этому феномену будет иметь идеологический характер. Отчасти по этому пути пошел Лукач в «Истории и классовом сознании» (1923). С точки зрения философа, впервые овеществление преодолевает пролетариат, когда он средствами мышления усматривает собственную субъективность в своем бытии в качестве объекта, порожденного и обусловленного капиталистическим способом производства. Становление самосознания пролетариата, обнаружение им за фетишизированными формами общественных отношений самого себя, является, по мнению Лукача, не только важным событием классовой борьбы, но и величайшим научным открытием, из которого в дальнейшем должны исходить революционные теория и практика (Лукач 2003, 253-257).

Однако для Беньямина такой подход не является бесспорным. Уже одна только вера в сознание, способное исключительно своими силами освободиться от овеществленных форм бытия, отмечена политическим идеализмом; вероятно, что здесь мы наталкиваемся на рудимент буржуазного мышления в самом центре философии марксизма (Погребняк 2018, 77). Но более того, в фетишистской видимости можно увидеть нечто большее, чем простое заблуждение субъекта. Само замещение, в котором отношения людей мистифицируются настолько, что принимают облик отношений товаров, открывает взгляду социального философа особый объект, который нельзя понять ни как чисто материальный, ни как идеальный. В таком случае можно сделать вывод, 
что фетишизация социальных связей приводит к становлению отдельной, нередуцируемой в рефлексии сферы кажимостей, которую мы могли бы вслед за Беньямином назвать фантасмагорией капиталистической культуры (Беньямин 2000, 158-160; Агамбен 2007, 302-307). Своим автономным статусом это предметно-фантастическое царство защищено от классической марксистской критики, восходящей к таким работам как «Святое семейство» (1845) и "Немецкая идеология» (1846). Так понятый товарный фетишизм оказывается теоретической проблемой, которая не может быть решена простым указанием на иллюзорность фетишистского замещения, а требует сформулировать изнутри самой вещной видимости язык для ее критического разоблачения ${ }^{17}$.

Как раз этим и занимается Беньямин. Полагая, что феномен товарного фетишизма является важнейшей философской проблемой, он признает, что вещный покров с общественных отношений можно снять лишь при помощи самих вещей. Видимость разгадывается из нее самой через определенное упорядочивание тех предметов, которые ее составляют. Отрицание снимается лишь в двойном отрицании. Для общества, законом которого стало овеществление социальной реальности, ее человеческий характер может быть раскрыт лишь посредством самих материальных продуктов овеществления, т. е. артефактов капиталистической культуры, по преимуществу разного рода старья. Оно исполняет синтетическую функцию, связывая людей с их отчужденной сущностью, подобно тому как в эссе Беньямина «Я распаковываю свою библиотеку» собранные книги становятся медиатором связи между автором и опытом прожитой жизни.

Поэтому Беньямин не противопоставляет капиталистическому фетишу коммунистический. Устаревшие вещи иначе соотносятся с человеческими надеждами, чем новые товары: первые их оживляют и освещают своим освобожденным от реалий современного общества существованием, вторые - сковывают и затеняют сетью идеологических значений. Обращение к устаревшим предметам следует уже упомянутой диалектике, когда в вещественно-плотном сне фантасмагории, окутавшем капиталистическое общество, открываются пути пробуждения. Если в основе товара как фетиша лежит двусмысленность, соединяющая утопическое сознание и цинизм рыночных отношений, то марксистская критика, согласно Беньямину, играет на этом напряжении. Она заставляет видимость, Schein, разоблачать себя в качестве таковой, т. е. представляет собой процедуру имманентной демистификации, Entmystifikation, фетишистской иллюзии (Eder 2014, 123-124) ${ }^{18}$.

Однако такое превращение не происходит само собой. Одного наличия устаревших вещей недостаточно для исполнения их мессианского предназначения. Они также должны быть взяты, увидены в определенном ракурсе,

17 Подробнее об этом см. также: Загвоздкин 2018.

18 Ту же диалектику Беньямин воспроизводит и по отношению к мифу в своем эссе о романе Гёте «Избирательное сродство» (1809). См. об этом: Джеймисон 2014, 121-123. 
и лишь на картине, выстроенной согласно линиям революционной перспективы, все эти вещи приобретут свой спасительный разворот. В связи с этим положениям проясняются место и роль наблюдателя в размышлениях Беньямина. Свой фазис вещи по-настоящему получают только во взгляде, который на них обращает субъект.

По замечанию философа, в основе такого виденья лежит не столько метод, сколько «фокус» («Trick», дословно «трюк»), заменяющий историческое отношение к произошедшему на политическое (Беньямин 20046, 269). Подражая Канту, Беньямин пишет о «коперниканском повороте» в историческом мышлении (Benjamin 1991с, 490-491), состоящем в придании активного залога не настоящему, а прошлому. То, что уже произошло, еще раз случается, на этот раз с нами. Ожидания предшествующих поколений, в том числе их политические требования, адресуются ныне живущим потомкам. Первоочередная задача современности заключается тогда в том, чтобы быть способной эти ожидания воспринять (Хабермас 2003, 23-26). Верный ракурс здесь тем более необходим, что сквозь призму господствующей идеологии все устаревшее предстает простым артефактов минувших дней и ничем более. Действительная связь времен теряется в подобной самотождественности, которую капитализм укрепляет, возводя те же «первые металлические конструкции» в предмет эстетического наслаждения. Так шоковое воздействие старья и его утопические интенции подменяются новым очарованием и органическими связями. Возникает опасность, что руина буржуазии станет товаром, доставляющим удовольствие сентиментальному потребителю (Беньямин 2004г, 378-380; Беньямин 2012г, 127-128; Беньямин 2012д 144-147 и др.).

Поэтому человек должен придать старому хламу тот образ, который позволит исторически-революционному измерению предметов состояться. Одной из подходящих техник здесь оказывается монтаж. Как раз с этой стороны Беньямин подходит к дадаизму. Картины, собранные из мусора вещественного, - и вторящие им стихи, сложенные из мусора словесного, - не просто коробят буржуазный вкус к прекрасному, а разрывают ту благоговейную ауру, которую общество создает вокруг культурных артефактов и слов. «Искусство превратилось у дадаистов в снаряд», шокирующий публику почти на тактильном уровне. Их коллажи не дают зрителям затеряться в созерцании, а побуждают их сфокусироваться. Вещи, освобожденные дадаистами от пользы и стоимости, требуют от наблюдателя вынести собственное суждение, тем самым воспитывая в нем самостоятельность. Так сказывается революционный посыл этого направления, который не ограничивается одной лишь областью эстетики (Беньямин 2012ж, 224-225) ${ }^{19}$.

19 В работе «Произведение искусства в эпоху его технической воспроизводимости» (1936) Беньямин упоминает лишь двух представителей этого течения: одного из его основоположников - Ханса Арпа (1886-1966), а также Августа Штрамма (1874-1915), рассматриваемого обычно в контексте родственного дадаизму экспрессионизма (Беньямин 2012ж, 224). 
Но конечно, ключевое значение в диалектической оптике Беньямина имеет фотография. Она является не просто технической новинкой или сенсацией в мире искусства, но принципиально новой формой для настройки нашего взгляда на вещи. Как и в случае с памятью, в человеческую способность здесь встраиваются внешние факторы, расширяя ее границы. Именно через объектив камеры мы можем увидеть революционный профиль мира вещей, переживших свою смерть и открывающихся нам сегодня по-новому.

Особенно привлекали Беньямина виды старых и бедных районов Парижа, к которым он вновь и вновь возвращается в своих текстах. Оттого ему были столь интересны работы Эжена Атже (1857-1927), французского фотохудожника, который отказался от удушливой атмосферы салона, чтобы привести фотографию на безлюдные улицы и обратить объектив к тем вещам, которые в этом нуждались. Беньямин пишет, что Атже «интересовало забытое и заброшенное <...> [Он] почти всегда проходил мимо “величественных видов и так называемых символов", но не пропускал длинный ряд сапожных колодок, не проходил мимо парижских дворов, где с вечера до утра стоят рядами ручные тележки, мимо не убранных после еды столов или скопившейся в огромном количестве грязной посуды... Как ни странно, на этих снимках почти нет людей» (Беньямин 2012г, 121-122). То, что изображает Атже - это «отчуждение между человеком и его окружением» (ibid., 123), антагонистическая социальная действительность, в которой человеку не находится места. Такие картины не вызывают то или иное настроение, а шокируют наблюдателя своей резкой правдивостью. В них мир вещей освобождается от всех утилитарно-рыночных связей. Сфотографированный Париж если и не становится домом для человека, то по крайней мере дает надежду на то, что когда-нибудь может им стать: «...город на этих снимках очищен, словно квартира, в которую еще не въехали новые жильцы» (ibid.). Конечно, фотограф приносит на суд истории свои работы, дабы выступить свидетелем эпохи эксплуатации и отчуждения. Но ему также суждено стать прорицателем, который предскажет будущее по его видимым знакам. Здесь дает о себе знать генеалогия фотографа: к его предкам Беньямин относит древнеримских авгуров и гаруспиков (ibid., 130; Беньямин 2012ж, 205).

Тесная связь фотографии и большого города позволяет написать их общую историю. Одним из ее центральных сюжетов стала бы классовая борьба буржуазии и пролетариата. Чтобы не позволить парижанам построить новые баррикады, Луи-Филипп I (1830-1848) хотел сделать все мостовые деревянными. При Наполеоне III (1848-1871) барон Осман провел полномасштабную перепланировку города, проложив новые пути от казарм в рабочие кварталы и превратив старые бульвары в широкие проспекты, на которых сложно держать оборону. Тем не менее в 1871 г. коммунары Парижа смогли перекрыть улицы линиями баррикад и траншей (Беньямин 2000, 164-166). То же самое, но на уровне образов, совершили Атже и сюрреалисты. Их фотографии показали город не как застывшую среду или предмет отстраненного любования, а как пространство, в котором возможно политическое действие. Изображенный 
ими Париж остается как будто бы незавершенным, замершим в ожидании бунта, который только и откроет истинный лик города. Зрителю хочется прервать молчание, царящее на этих снимках, однако он понимает, что для этой цели достаточно громкими будут не слова, а звуки пуль и свистков (Беньямин 20046, 270; Беньямин 2012г, 123) 20.

Каждая такая фотография - и, шире, всякий подлинный образ реальности - является результатом конструкции. Только расставив и повернув предметы определенным способом, человек придаст им, словами Маркса, «всемирно-историческое значение». Синтез вещественности и истории вспыхивает лишь в таких констелляциях. Они же позволяют реализовать мессианский потенциал, заключенный в старом хламе и ждущий своего высвобождения. Необходимость правильно выстроить перспективу сближает революционного интеллектуала с инженером и техником. По этому поводу Беньямин цитирует Брехта: положение революционного художника «столь сложно потому, что менее чем когда-либо простое "воспроизведение реальности" что-либо говорит о реальности... Истинная реальность ускользнула в сферу функционального. Опредмеченность человеческих отношений, например на фабрике, больше не выдает этих отношений. Потому действительно необходимо “нечто строить", нечто “искусственное”, нечто “заданное”» (ibid., 128).

Можно предположить, что поздняя философия Беньямина в значительной степени была поиском способов сконструировать те образы, в которых предметность современного ему мира пересеклась бы с историей. Если принять эту гипотезу, то как части одной интеллектуальной оптики можно объединить самые разные тексты: от толкований авангарда до работ о кино, фотографии и репродукции. Среди всех этих трудов возвышается проект «Пассажей» неоконченная книга о физиогномике XIX в., задуманная как взгляд назад из тяжелых и мрачных времен 20-30-х гг. XX в. В отличие от позиции Пруста, смирившегося со случайностью своей практики, у Беньямина мы видим активную установку на определенное, поддающееся тренировке восприятие. При этом он не возводит свой взгляд на вещи в систему, а скорее диалектически (и одновременно эротически) снимает его ограниченность: привязанность к вещам становится «неволей по собственной воле», дающей возможность

20 Для целей настоящей статьи мы ограничились буквальным пониманием фотографии у Беньямина, взяв в скобки ее аллегорический смысл. Чтобы проникнуть в него, следовало бы внимательно вчитаться в одно остроумное замечание все того же Бретона. Назвав автоматическое письмо фотографией мысли, писатель подсказал нам, как следовало бы толковать язык работ Беньямина: как серию снимков его размышлений. В работах философа мысль опосредована этой фотографической манерой письма, в результате чего рассуждение предстает перед читателем как ряд концептуальных целостностей, каждая из которых, подобно отдельным снимкам фотоколлажа, имеет свою композицию и предполагает соответствующую перспективу. Действительно, такие тексты как «Улица с односторонним движением» (1926), «Московский дневник» (1927) и "Берлинское детство на рубеже веков» являются продуктами литературно-философского монтажа, составленными из различных сцен, сентенций и комментариев (Джеффрис 2018, 114). Дальнейшее исследование этого аспекта философии Беньямина, однако, увело бы нас слишком далеко от обозначенной темы. 
искать аллегорические соответствия между разными планами бытия (см.: Погребняк 2018, 67-69).

Как и в ранних работах, вещественный облик истории, зафиксированный в поздних сочинениях, является не художественным тропом или логическим допущением, а реальной метаморфозой сфер предметного и исторического, дающей человеку шанс на спасение. В частности, особый временной статус устаревших вещей предопределяет их социально-историческую функцию в буржуазном обществе. Образы старого хлама обладают шоковым воздействием, которое готовит наблюдателя к политической практике и служит катализатором революции. Ткань сна прорывается грезами о давно минувшем, фетишистская видимость диалектически снимается согласно закону собственного развития. Но, кроме того, когда время опредмечивается в исторических артефактах, человек может складывать из них, словно из осколков, мозаику спасенной истории. Первые металлические конструкции, немые руины прошлых триумфов капиталистической индустрии, визуализированные на фотографиях Атже или в романе Бретона, показывают нам мир, избавленный от отношений товарного производства и потому достигший свободы. Возможно даже, что в этот момент устаревшие, бесполезные вещи образуют некий новый язык, гораздо более пригодный для выражения утопических стремлений современности, чем вся философская терминология или даже человеческий язык как таковой.

Сказанное позволяет нам вернуться в самое начало, чтобы дать ответ на вопрос, чем же были для Беньямина барочный реквизит, старые книги и металлические конструкции. Для начала, все это - конкретные образы, в которых история выходит за свои пределы, чтобы принять вещественный облик и стать предметом человеческой практики. Насколько отличаются способы этой трансформации (аллегория, коллекция, хлам) и виды ее репрезентации (театр, воспоминание, революция), настолько же общими для них являются два принципа: действительность такого превращения исторического в вещественное и его мессианский смысл. В трех частях настоящей работы эти вариации одного синтеза были подробно изложены и контекстуализированы.

Вместе с тем, эти фигуры, в которых для Беньямина совершалось превращение того или иного пласта истории в собственный монумент, выражают и те формы, в которых двигалась и жила мысль автора. Как сказано в книге о немецком барокко, сердцевинной философской работы является ее способ изложения (Darstellung), а не содержание, ее «как», а не «что» (Беньямин $2002,5-7)$. То или иное интеллектуальное виденье манифестирует себя уже на уровне письма и чтения. Отсюда следует, что если утопию и спасение можно выразить лишь с помощью вещей, то сама философия должна решиться на то, чтобы - в некотором отношении - сделать свой язык предметным ${ }^{21}$. В таком случае свободно льющийся поток письма или величественно стоящая система

21 О том, насколько глубоко это, по сути, аллегорическое виденье пронизывает философию Беньямина, см. также: Джеймисон 2014, 116-118, 123, 128-130; Левашов 2015. 
перестают быть законными моделями рассуждения. Язык философии становится скорее собранием отдельных элементов, которые разум рассматривает с тем же любопытством, с которым коллекционер перебирает старые книги.

Каждый мыслимый предмет здесь - это отдельный мир со своими предпосылками, терминологией, персоналиями, проблемами и решениями. Но, несмотря на это, общая нить ведет от одного отрывка к другому, позволяя проступить контурам целого. Как раз такой путь - философию как блуждание между ее же собственными фрагментами - и предлагает нам Вальтер Беньямин, фланируя на страницах своих текстов среди картонных королей, старых книг и металлических конструкций.

\section{СПИСОКЛИТЕРАТУРЫ}

Benjamin W. (1991a) «Ursprung des deutschen Trauerspiels». Benjamin W. Gesammelte Schriften. Bd. I-VII. Bd. I. Teil. 1. Hrsg. von R. Tiedemann und H. Schweppenhäuser. Frankfurt am Main: Suhrkamp Verlag. S. 203-431.

Benjamin W. (1991b) «Über einige Motive bei Baudelaire». Benjamin W. Gesammelte Schriften. Bd. I-VII. Bd. I. Teil. 2. Hrsg. von R. Tiedemann und H. Schweppenhäuser. Frankfurt am Main: Suhrkamp Verlag. S. 605-655.

Benjamin W. (1991c) «Über den Begriff der Geschichte» (mit Anmerkungen der Herausgeber). Benjamin W. Gesammelte Schriften. Bd. I-VII. Bd. I. Teil. 2-3. Hrsg. von R. Tiedemann und H. Schweppenhäuser. Frankfurt am Main: Suhrkamp Verlag. S. 691-706, 1223-1272.

Benjamin W. (1991d) «Der Surrealismus. Die letzte Momentaufnahme der europäischen Intelligenz». Benjamin W. Gesammelte Schriften. Bd. I-VII. Bd. II. Teil. 1. Hrsg. von R. Tiedemann und H. Schweppenhäuser. Frankfurt am Main: Suhrkamp Verlag. S. 295-310.

Benjamin W. (1991e) «Ausgraben und Erinnern». Benjamin W. Gesammelte Schriften. Bd. I-VII. Bd. IV. Teil. 1. Hrsg. von T. Rexroth. Frankfurt am Main: Suhrkamp Verlag. S. $400-401$.

Benjamin W. (1991f) «Das Passagen-Werk». Benjamin W. Gesammelte Schriften. Bd. IVII. Bd. V. Teil. 1-2. Hrsg. von R. Tiedemann.Frankfurt am Main: Suhrkamp Verlag.

Eder B. (2014) "TräumerInnen im Wachen». (K)ein Ende der Kunst. Kritische Theorie, Ästhetik, Gesellschaft. Hrsg. von B. Marschall, C. Schulte, S. Vorwalder, F. Wagner. Münster: LIT Verlag. S. 121-138.

Emden C. (2003) "Nachleben": Cultural Memory in Aby Warburg and Walter Benjamin». Cultural Memory: Essays on European Literature and History. Ed. by E. Caldicott, A. Fuchs. Bern: Peter Lang. P. 209-224.

Steiner U. (2004) Walter Benjamin. Stuttgart; Weimar: Verlag J. B. Metzler (Sammlung Metzler. Bd. 350).

Агамбен Д. (2007) «Стансы. Слово и фантазм в западной культуре». Vita Cogitans. № 5. С. 295-332.

Адорно Т., Хоркхаймер М. (1997) Диалектика просвещения. Философсккие фрагменты. М.; СПб.: Медиум; Ювента.

Адорно Т. (2003) Негативная диалектика. М.: Научный мир. 
Арендт Х. (2003) «Вальтер Беньямин (1892-1940)». Арендт Х. Люди в темные времена. М.: Московская школа политических исследований (Культура, политика, философия). С. 175-237.

Бекмеметьев В. (2016) “"Мусор истории”: спасение вещей как актуализация прошлого». Культурная память и культурная идентичность: материалы Всероссийской (с международным участием) научной конфреренции молодых ученых (ХІ Колосницынские чтения). Екатеринбург: Издательство Уральского университета. С. 27-31.

Беньямин В. (2000) «Париж, столица XIX столетий». Беньямин В. Озарения. М.: Мартис. С. 153-167.

Беньямин В. (2002) Происхождение немецкой барочной драмы. М.: Аграф.

Беньямин В. (2004а) «К портрету Пруста». Беньямин В. Маски времени. Эссе о культуре и литературе. Сост., предисл. и прим. А. Белобратова. СПб.: Симпозиум. С. 243-262.

Беньямин В. (20046) «Сюрреализм: последняя моментальная фотография европейской интеллигенции». Беньямин В. Маски времени. Эссе о культуре и литературе. Сост., предисл. и прим. А. Белобратова. СПб.: Симпозиум. С. 263-282.

Беньямин В. (2004в) «Теории немецкого фашизма. О сборнике Эрнста Юнгера "Война и воины"». Беньямин В. Маски времени. Эссе о культуре и литературе. Сост., предисл. и прим. А. Белобратова. СПб.: Симпозиум. С. 359-375.

Беньямин В. (2004г) «Левая меланхолия. О новой книге стихов Эриха Кестнера». Беньямин В. Беньямин В. Маски времени. Эссе о культуре и литературе. Сост., предисл. и прим. А. Белобратова. СПб.: Симпозиум. С. 376-382.

Беньямин В. (2004д) «Я распаковываю свою библиотеку. Речь о коллекционировании». Беньямин В. Маски времени. Эссе о культуре и литературе. Сост., предисл. и прим. А. Белобратова. Спб.: Симпозиум. С. 433-444.

Беньямин В. (2012а) Берлинское детство на рубеже веков. М.: Ад Маргинем; Екатеринбург: Кабинетный ученый (Библиотека журнала «Логос»).

Беньямин В. (20126) «О программе грядущей философии». Беньямин В. Учение о подобии. Медиаэстетические произведения. Сост. и послеслов. И. Чубарова, И. Болдырева. М.: Изд-во РГГУ (Современные гуманитарные исследования. Кн. І). С. 31-51.

Беньямин В. (2012в) «Капитализм как религия». Беньямин В. Учение о подобии. Медиаэстетические произведения. Сост. и послеслов. И. Чубарова, И. Болдырева. М.: Изд-во РГГУ (Современные гуманитарные исследования. Кн. І). С. 100-108.

Беньямин В. (2012г) «Краткая история фотографии». Беньямин В. Учение о подобии. Медиаэстетические произведения. Сост. и послеслов. И. Чубарова, И. Болдырева. М.: Изд-во РГГУ (Современные гуманитарные исследования. Кн. I). С. 109-132.

Беньямин В. (2012д) «Автор как производитель. Выступление в Институте по изучению фашизма в Париже 27 апреля 1934 г.». Беньямин В. Учение о подобии. Медиаэстетические произведения. Сост. и послеслов. И. Чубарова, И. Болдырева. М.:Изд-во РГГУ (Современные гуманитарные исследования. Кн. І). С. 133-163.

Беньямин В. (2012е) «Учение о подобии». Беньямин В. Учение о подобии. Медиаэстетические произведения. Сост. и послеслов. И. Чубарова, И. Болдырева. М.: Изд-во РГГУ (Современные гуманитарные исследования. Кн. І). С. 164-187. 
Беньямин В. (2012ж) «Произведение искусства в эпоху его технической воспроизводимости». Беньямин В. Учение о подобии. Медиаэстетические произведения. Сост. и послеслов. И. Чубарова, И. Болдырева. М.: Изд-во РГГУ (Современные гуманитарные исследования. Кн. І). С. 190-234.

Беньямин В. (20123) «О понятии истории». Беньямин В. Учение о подобии. Медиаэстетические произведения. Сост. и послеслов. И. Чубарова, И. Болдырева. М.: Изд-во РГГУ (Современные гуманитарные исследования. Кн. І). С. 237-253.

Беньямин В. (2013) «Франц Кафка». Беньямин В. Франц Кафка. М.: Ад Маргинем. С. 7-47.

Беньямин В. (2015а) «Шарль Бодлер. Поэт в эпоху зрелого капитализма». Беньямин В. Бодлер. М.: Ад Маргинем. С. 7-185.

Беньямин В. (20156) «О некоторых мотивах у Бодлера». Беньямин В. Бодлер. М.: Ад Маргинем. С. 117-173.

Беньямин В. (2015в) «Центральный парк». Беньямин В. Бодлер. М.: Ад Маргинем. С. $187-220$.

Болдырев И. (2012) Время утопии. Проблематические основания и контексты философии Эрнста Блоха. М.: Изд. дом Высшей школы экономики (Исследования культуры).

Джеймисон Ф. (2014) «Вальтер Беньямин, или Ностальгия». Джеймисон Ф. Марксизм и интерпретация культуры. Составитель А. А. Парамонов. М.; Екатеринбург: Кабинетный ученый. С. 116-136.

Джеффрис С. (2018) Гранд-Отель «Бездна». Биография франкфуртской школы. М.: Ад Маргинем.

Загвоздкин Н. (2018). «К истории одной загадки: понятие товарного фетишизма в философии Маркса». Философия марксизма. История и современность. К 200-летию со дня рождения Карла Маркса. Под ред. И. Д. Осипова, С. Н. Погодина. СПб.: Политех-Пресс. С. 243-263.

Иглтон Т. (2009) Марксизм и литературная критика. М.: Свободное марксистское издательство.

Левашов В. (2015) «Читать и разгадывать: Вальтер Беньямин о фотографии». Беньямин В. Краткая история фотографии. М.: Ад Маргинем. С. 140-164.

Лукач Д. (2003) История и классовое сознание. Исследования по марксистской диалектике. М.: Логос-Альтера (Левая карта).

Маркс К. (2015) Капитал. Критика политической экономии. Т. І. М.: Манн, Иванов и Фербер.

Погребняк А. (2018) «Морщины и игрушки Вальтера Беньямина: “Московский дневник" как испытание метода». Логос. Философско-литературный журнал. № 1 (122). С. 59-86.

Ромашко С. (2002) «Драматика литературы и драматика жизни». Беньямин В. Происхождение немецкой барочной драмы. М.: Аграф. С. 271-281.

Таганов А. (2015) «Беньямин и Пруст». Шарль Бодлер \& Вальтер Беньямин. Политика \& Эстетика. Коллективная монография по материалам международного научного симпозиума, состоявшегося 20-21 апреля 2008 года в Институте русской литературы РАН (Пушкинский Дом) в ознаменование 150-летия выхода в свет «Цветов зла». М.: Новое литературное обозрение (Научная библиотека). С. 147-261. 
Травников С. К. (2015) «Роль непроизвольной памяти в диалектике сна и пробуждения Вальтера Беньямина (Проект “Пассажи”)». Артикульт. № 3 (19). С. 29-34.

Хабермас Ю. (2003) Философский дискурс о модерне. М.: Весь мир (Тема).

чубаров И. (2012) «Беньямин Шмитту не товарищ, или Ошибка Агамбена». Логос. Философско-литературный журнал. № 5 (89). С. 44-67.

Энгельс Ф. (1961) «Развитие социализма от утопии к науке». Маркс К., Энгельс Ф. Сочинения. 2-е изд. В 50 т. Т. 19. М.: Издательство политической литературы. C. $185-230$.

\title{
THE SUBSTANTIVITY OF HISTORY: WALTER BENJAMIN AMID CARDBOARD KINGS, OLD BOOKS, AND METALLIC CONSTRUCTIONS
}

\author{
Nikita Zagvozdkin \\ Master's Student, University of Wuppertal. \\ Address: Gaußstraße 20, 42119, Wuppertal, Germany. \\ E-mail:zagvnd@gmail.com \\ KEYWORDS:Benjamin, history, things, reification, German tragic drama, collecting, \\ ruins of bourgeoisie, commodity fetishism, photography, fragment.
}

The article discusses the range of images and simultaneously thought figures that Walter Benjamin continuously used during various periods of his work to constitute and conceive the relation between things and history. For this purpose, the following points of attraction of his thought and imagination are empathized in the variety of insights, suggestions, and interconnections, which form the field of Benjamin's philosophy: props of the Baroque theater, collections of old books, and metallic constructions shaping the landscape of early capitalistic industry. Each one of these groups is considered to express a certain mode of reification of history, which introduces it into the boundaries of human practice, giving thereby one a promise of salvation in the problematic situation of epoch. The allegorical condensation of time within the stage props makes it dramatically amendable; the inclusion of objects into the context of involuntary memory (Proust) gives one a chance to reclaim past experiences in a meaningful integrity of impression; the outdated symbols of class domination of bourgeoisie wake the revolutionary subject from its ideological dream and constellate the image of future utopia. In all three cases, the reality of the transformation of history into an object and its messianic potential are identified as general framework of Benjamin's account on the subject. Yet, each synthesis of time and substantiality imposes its own perspective: dramatically aesthetical, mnemonically transcendental, and socially political. Accordingly, the analyzed texts differ thematically and in terms of methodic prerequisites of their organization, as well as in terms of the cited personalities. At the end of the article, this complex of discrepancies is traced back to the language of Benjamin's writing since the philosopher tends to simultaneously separate and conjoin elements of his thinking, treating the emerging whole as an elaborate intellectual mosaic. Therefore, the structure and form of the article are grasped as a methodological reflection of the examined subject matter.

\section{REFERENCES}

Adorno T. (2003) Negative Dialektik. Moscow: Nauchnyi mir. (in Russian).

Adorno T., Horkheimer M. (1997) Dialektik der Aufklärung. Philosophische Fragmente. Moscow; St. Petersburg: Medium; Yuventa. (in Russian). 
Agamben G. (2007) "Stanze. La parola e il fantasma nella cultura occidentale". Vita Cogitans. No. 5: 295-332. (in Russian).

Arendt H. (2003) "Walter Benjamin (1892-1940)". Arendt H. Menschen in finsteren Zeiten. Moscow: Moskovskaya shkola politicheskih issledovanij (Kul'tura, politika, filosofiya [Culture, Politics, Philosophy]): 175-237. (in Russian).

Bekmemetev V. (2016) "Musor istorii': spasenie veshchej kak aktualizaciya proshlogo" ["The trash of history": do things find their redemption?]. Kul'turnaya pamyat' $i$ kul'turnaya identichnost': materialy Vserossijskoj (s mezhdunarodnym uchastiem) nauchnoj konferencii molodyh uchenyh (XI Kolosnicynskie chteniya) [Cultural Memory and Cultural Identity: Materials of All-Russia academic conference of young scientists with international participation (XI Kolosnitsyn readings)]. Yekaterinburg: Izdatel'stvo Ural'skogo universiteta: 27-31. (in Russian).

Benjamin W. (1991a) "Ursprung des deutschen Trauerspiels". Benjamin W. Gesammelte Schriften. Bd. I-VII. Bd. I. Teil. 1 (hg. v. R. Tiedemann und H. Schweppenhäuser). Frankfurt am Main: Suhrkamp Verlag: 203-431.

Benjamin W. (1991b) “Über einige Motive bei Baudelaire”. Benjamin W. Gesammelte Schriften. Bd. I-VII. Bd. I. Teil. 2 (hg. v. R. Tiedemann und H. Schweppenhäuser). Frankfurt am Main: Suhrkamp Verlag: 605-655.

Benjamin W. (1991c) "Über den Begriff der Geschichte" (mit Anmerkungen der Herausgeber). Benjamin W. Gesammelte Schriften. Bd. I-VII. Bd. I. Teil. 2-3 (hg. v. R. Tiedemann und H. Schweppenhäuser). Frankfurt am Main: Suhrkamp Verlag: 691-706, 1223-1272.

Benjamin W. (1991d) "Der Surrealismus. Die letzte Momentaufnahme der europäischen Intelligenz". Benjamin W. Gesammelte Schriften. Bd. I-VII. Bd. II. Teil. 1 (hg. v. R. Tiedemann und H. Schweppenhäuser). Frankfurt am Main: Suhrkamp Verlag: 295-310.

Benjamin W. (1991e) "Ausgraben und Erinnern". Benjamin W. Gesammelte Schriften. Bd. I-VII. Bd. IV. Teil. 1 (hg. v. Rexroth). Frankfurt am Main: Suhrkamp Verlag: 400-401.

Benjamin W. (1991f) "Das Passagen-Werk". Benjamin W. Gesammelte Schriften. Bd. I-VII. Bd. V. Teil. 1-2 (hg. v. R. Tiedemann). Frankfurt am Main: Suhrkamp Verlag.

Benjamin W. (2000) "Paris, Capitale du XIXème siècle". Benjamin W. Illuminationen. Ausgewählte Schriften. Moscow: Martis: 153-167. (in Russian).

Benjamin W. (2002) Ursprung des deutschen Trauerspiels. Moscow: Agraf. (in Russian).

Benjamin W. (2004a) "Zum Bilde Prousts". Benjamin W. Maski vremeni. Esse o kul'ture i literature [Masks of Time. Essays on Culture and Literature] (coll., intr., notes by A. Belobratov). St. Petersburg: Simpozium: 243-262. (in Russian).

Benjamin W. (2004b) "Der Surrealismus. Die letzte Momentaufnahme der europäischen Intelligenz". Benjamin W. Maski vremeni. Esse o kul'ture i literature [Masks of Time. Essays on Culture and Literature] (coll., intr., notes by A. Belobratov). St. Petersburg: Simpozium: 263282. (in Russian).

Benjamin W. (2004c) "Theorien des deutschen Faschismus. Zu der Sammelschrift 'Krieg und Krieger'. Herausgegeben von Ernst Jünger". Benjamin W. Maski vremeni. Esse o kul'ture i literature [Masks of Time. Essays on Culture and Literature] (coll., intr., notes by A. Belobratov). St. Petersburg: Simpozium: 359-375. (in Russian).

Benjamin W. (2004d) "Linke Melancholie. Zu Erich Kästners neuem Gedichtbuch". Benjamin W. Maski vremeni. Esse o kul'ture i literature [Masks of Time. Essays on Culture and Literature] (coll., intr., notes by A. Belobratov). St. Petersburg: Simpozium: 376-382. (in Russian).

Benjamin W. (2004e) "Ich packe meine Bibliothek aus. Eine Rede über das Sammeln". Benjamin W. Maski vremeni. Esse o kul'ture i literature [Masks of Time. Essays on Culture and Literature] (coll., intr., notes by A. Belobratov). St. Petersburg: Simpozium: 433-444. (in Russian).

Benjamin W. (2012a) Berliner Kindheit um Neunzehnhundert. Moscow: Ad Marginem; Yekaterinburg: Kabinetnyj uchenyj (Biblioteka zhurnala "Logos" [library of the "Logos" magazine]). (in Russian). 
Benjamin W. (2012b) “Über das Programm der kommenden Philosophie”. Benjamin W. Uchenie o podobii. Mediaesteticheskie proizvedeniya [Doctrine of Similarity. Mediaaesthetic Works] (ed. by I. Chubarov, I. Boldyrev). Moscow: Izd-vo RGGU (Sovremennye gumanitarnye issledovaniya. Kn. I [Present day humanistic studies. Vol. I]): 31-51. (in Russian).

Benjamin W. (2012c) "Kapitalismus als Religion". Benjamin W. Uchenie o podobii. Mediaesteticheskie proizvedeniya [Doctrine of Similarity. Mediaaesthetic Works] (ed. by I. Chubarov, I. Boldyrev). Moscow: Izd-vo RGGU (Sovremennye gumanitarnye issledovaniya. Kn. I [Present day humanistic studies. Vol. I]): 100-108. (in Russian).

Benjamin W. (2012d) "Kleine Geschichte der Fotografie". Benjamin W. Uchenie o podobii. Mediaesteticheskie proizvedeniya [Doctrine of Similarity. Mediaaesthetic Works] (ed. by I. Chubarov, I. Boldyrev). Moscow: Izd-vo RGGU (Sovremennye gumanitarnye issledovaniya. Kn. I [Present day humanistic studies. Vol. I]): 109-132. (in Russian).

Benjamin W. (2012e) "Der Autor als Produzent. Ansprache im Institut zum Studium des Fascismus in Paris am 27. April 1934". Benjamin W. Uchenie o podobii. Mediaesteticheskie proizvedeniya [Doctrine of Similarity. Mediaaesthetic Works] (ed. by I. Chubarov, I. Boldyrev). Moscow: Izd-vo RGGU (Sovremennye gumanitarnye issledovaniya. Kn. I [Present day humanistic studies. Vol. I]): 133-163. (in Russian).

Benjamin W. (2012f) "Lehre vom Ähnlichen". Benjamin W. Uchenie o podobii. Mediaesteticheskie proizvedeniya [Doctrine of Similarity. Mediaaesthetic Works] (ed. by I. Chubarov, I. Boldyrev). Moscow: Izd-vo RGGU (Sovremennye gumanitarnye issledovaniya. Kn. I [Present day humanistic studies. Vol. I]): 164-187. (in Russian).

Benjamin W. (2012g) "Das Kunstwerk im Zeitalter seiner technischen Reproduzierbarkeit". Benjamin W. Uchenie o podobii. Mediaesteticheskie proizvedeniya [Doctrine of Similarity. Mediaaesthetic Works] (ed. by I. Chubarov, I. Boldyrev). Moscow: Izd-vo RGGU (Sovremennye gumanitarnye issledovaniya. Kn. I [Present day humanistic studies. Vol. I]): 190-234. (in Russian).

Benjamin W. (2012h) "Über den Begriff der Geschichte". Benjamin W. Uchenie o podobii. Mediaesteticheskie proizvedeniya [Doctrine of Similarity. Mediaaesthetic Works] (ed. by I. Chubarov, I. Boldyrev). Moscow: Izd-vo RGGU (Sovremennye gumanitarnye issledovaniya. Kn. I [Present day humanistic studies. Vol. I]): 237-253. (in Russian).

Benjamin W. (2013) "Franz Kafka”. Benjamin W. Frantz Kafka. Moscow: Ad Marginem: 7-47. (in Russian).

Benjamin W. (2015a) “Charles Baudelaire. Ein Lyriker im Zeitalter des Hochkapitalismus". Benjamin W. Baudelaire. Moscow: Ad Marginem: 7-116. (in Russian).

Benjamin W. (2015b) "Über einige Motive bei Baudelaire". Benjamin W. Baudelaire. Moscow: Ad Marginem: 117-186. (in Russian).

Benjamin W. (2015c) "Zentralpark". Benjamin W. Baudelaire. Moscow: Ad Marginem: 187-220. (in Russian).

Boldyrev I. (2012) Vremya utopii. Problematicheskie osnovaniya i konteksty filosofii Ernsta Blocha [Time of Utopia. Problematic Foundations and Contexts of the Ernst Bloch's Philosophy]. Moscow: Izdatel'skii dom Vysshei shkoly ekonomiki. (in Russian).

Chubarov I. (2012) "Benjamin Schmittu ne tovarishch, ili Oshibka Agambena» [Benjamin is no comrade to Schmitt, or Agamben's Mistake]. Logos. Filosofsko-literaturnyi zhurnal. № 5 (68) [Logos. A philosophical and literary journal. No. 5 (89)]: 44-67. (in Russian).

Eagleton T. (2009) Marxism and Literary Criticism. Moscow: Svobodnoe marksistskoe izdatel'stvo. (in Russian).

Eder B. (2014) "TräumerInnen im Wachen". (K)ein Ende der Kunst. Kritische Theorie, Ästhetik, Gesellschaft (hg. v. B. Marschall, C. Schulte, S. Vorwalder, F. Wagner). Münster: LIT Verlag: 121-138.

Emden C. (2003) “'Nachleben': Cultural Memory in Aby Warburg and Walter Benjamin”. Cultural Memory: Essays on European Literature and History (ed. by E. Caldicott, A. Fuchs). Bern: Peter Lang: 209-224. 
Engels F. (1961) "Die Entwicklung des Sozialismus von der Utopie zur Wissenschaft". Marx K., Engels F. Sochineniya. 2-e izd. V 50 t. T. 19 [Works. 2 ed. In 50 vol. Vol. 19]. Moscow: Izdatel'stvo politicheskoi literatury: 185-230. (in Russian).

Habermas J. (2003) Der philosophische Diskurs der Moderne. Zwölf Vorlesungen. Moscow: Ves' mir (Tema). (in Russian).

Jameson F. (2014) “Walter Benjamin, or Nostalgia”. Jameson F. Marksizm i interpretatsiya kul'tury [Marxism and Interpretation of Culture] (coll. by A. A. Paramonov). Moscow; Yekaterinburg: Kabinetnyj uchenyj: 116-136. (in Russian).

Jeffries S. (2018) Grand Hotel "Abyss": The Lives of the Frankfurt School. Moscow: Ad Marginem. (in Russian).

Levashov V. (2015) "Chitat' i razgadyvat': Walter Benjamin o fotografii" [Reading and Solving: Walter Benjamin on Photography]. Benjamin W. Kratkaya istoriya fotografii [Short History of Photography]. Moscow: Ad Marginem. (in Russian).

Lukács G. (2003) Geschichte und Klassenbewußtsein. Studien über marxistische Dialektik. Moscow: Logos-Al'tera (Levaya karta [Leftist card]). (in Russian).

Marx K. (2015) Das Kapital. Kritik der politischen Oekonomie. Erster Band. Moscow: Mann, Ivanov i Ferber. (in Russian).

Pogrebnyak A. (2018) “Morshchiny i igrushki Walter Benjamina: 'Moskovskii dnevnik' kak ispytanie metoda" [The Wrinkles and Toys of Walter Benjamin: "The Moscow Diary" as a Method Appraisal]. Logos. Filosofsko-literaturnyi zhurnal. № 1 (122) [Logos. A philosophical and literary journal. No. 1 (122)]: 59-86. (in Russian).

Romashko S. (2002) "Dramatika literatury i dramatika zhizni" [Dramatics of Literature and Dramatics of Life]. Benjamin W. Ursprung des deutschen Trauerspiels. Moscow: Agraf: 271-281. (in Russian).

Steiner U. (2004) Walter Benjamin. Stuttgart; Weimar: Verlag J. B. Metzler (Sammlung Metzler. Bd. 350).

Taganov A. (2015) "Benjamin i Proust" [Benjamin and Proust]. Charles Baudelaire \& Walter Benjamin. Politika \& Estetika. Kollektivnaya monografiya po materialam mezhdunarodnogo nauchnogo simpoziuma, sostoyavshegosya 20-21 aprelya 2008 goda v Institute russkoj literatury RAN (Pushkinskij Dom) v oznamenovanie 150-letiya vyhoda v svet "Cvetov zla" [Charles Baudelaire \& Walter Benjamin. Politics \& Aesthetics. Collctive monograph on materials of the international scientific symposium held on April 20-21, 2008, in the Institute of Russian Literature of the Russian Academy of Science (Pushkin House) in commemoration of 150th anniversary of first publication of "The Flowers of Evil"]. Moscow: Novoe literaturnoe obozrenie (Nauchnaya biblioteka [Scientific library]). (in Russian).

Travnikov S. K. (2015) “Rol' neproizvol'noi pamyati v dialektike sna i probuzhdeniya Walter Benjamina (Proekt 'Passazhi')" [A Conceptual Role of "La Mémoire Involontaire" in Walter Benjamin's Dialectics of Dream and Awakening (“Arcades" Project)]. Artikul't. № 3 (19) [Art \& Cult. No. 3 (19)]: 29-34. (in Russian).

Zagvozdkin N. (2018) "K istorii odnoi zagadki: ponyatie tovarnogo fetishizma v filosofii Marksa" [History of One Riddle: The Concept of Commodity Fetishism in the Philosophy of Marx]. Filosofiya marksizma. Istoriya i sovremennost'. K 200-letiyu so dnya rozhdeniya Karla Marksa [Philosophy of Marxism. History and the Present. To 200th anniversary of Karl Marx]. St. Petersburg: Politekh-Press: 243-263. (in Russian).

DOI: https://doi.org/10.31119/essephts.2019.4.1.2

ESSE: Studies in Philosophy and Theology. Vol. 4. No. 1. 2019. P. 43-72.

(C) Nikita Zagvozdkin, 2019 